\title{
A Hermeneutics of SEXUAl IDENTity: A CHAllenge to CONSERVATIVE RELIGIOUS DISCOURSE
}

Author:

Samuel Hill

\section{Affiliation:}

${ }^{1}$ Faculty of Humanities, University of Johannesburg, South Africa

\section{Correspondence to:} Samuel Hill

e-mail:

planetbruce@gmail.com

Postal address:

99 Railway St., Mayfair, Johannesburg, 2092,

South Africa

\section{Keywords:}

homogenital acts; queer theory; Deuteronomistic history; Jewish national grand narrative; politics of survival

\section{Dates:}

Received: 02 Sept. 2008

Accepted: 26 Apr. 2009

Published: 06 Nov. 2009

How to cite this article:

Hill, S., 2009, 'A

hermeneutics of sexual identity: A challenge to conservative religious discourse', Verbum et Ecclesia 30(2), Art. \#92, 6 pages. DOI: 10.4102/ve.v30i2.92

\section{This article is available} at:

http://www.ve.org.za
(C) 2009. The Authors. Licensee: OpenJournals Publishing. This work is licensed under the

Creative Commons

Attribution License.

\section{ABSTRACT}

I argue that since two significant periods (that form part of what is called 'Deuteronomistic history') in the history of the Jews contributed to the development of the Biblical narrative in the format that we have it in today, it can be said that what we have in the Old Testament is really a Jewish national grand narrative. As such, part of the function of this text is to create a strong national identity for the purpose of a people to survive as a people in a hostile environment. Understanding the Old Testament (specifically the books Genesis to II Kings) in this way, and using the insights of the queer theorist Judith Butler with regard to performativity and interpellation, I demonstrate that the Biblical narrative, while condemning homogenital acts, nevertheless has limited application when trying to establish normative guidelines around contemporary issues regarding sexual identity, especially homosexuality, since laws and attitudes that are seen to proscribe homogenital activity arose in a context of a politics of survival.

\section{INTRODUCTION}

In what can be called the 'gay-debate' (Punt 2007:965) there is tension between two extremes around which the controversy concerning homosexuality and the Bible revolve. This tension can be expressed in terms of an 'essentialist' school of thought versus a 'constructionist' school of thought (Weeks 2000: 130) or, to put it another way, a distinction is made between 'chromosomally determined sex [as opposed to - SH] culturally constructed gender' (Andrew Parker, cited in Warner 1993:20). Much of the literature in the gay debate over the past decade or so has already covered this ground, so much so that it would be superfluous for me even to attempt to give a brief survey of such current literature.

Instead what I do in this article is to address the issue of homosexuality and the Bible from a hermeneutical perspective. Anthony Thiselton, in his article Can hermeneutics ease the deadlock? Some Biblical exegesis and hermeneutical models (Thiselton, cited in Bradshaw 2003:145), has attempted to address the issue of homosexuality and the Bible from a hermeneutical perspective. However, in my opinion he does so unsatisfactorily in that he fails to take seriously the historical and linguistic situatedness of certain words or concepts with regard to this debate. For instance, he insists that the apostle Paul knew of 'homosexuality' (Thiselton, cited in Bradshaw 2003:188), which is clearly to commit an anachronistic fallacy with regard to the modern-day concept of homosexual (Stone 2001:24; Weeks 2000:24-25), as such a concept cannot be said to occur in the Bible. Therefore, what I argue, using hermeneutical insights, is that, while the Bible does condemn homogenital acts, it does not condemn homosexuality. Furthermore, I argue that such condemnation of homogenital acts takes place in the context of a politics of survival. In the course of my argument, using the insights of queer theory, I shall be looking at 'sexual identity as [SH] a fiction' (Weeks 2000:192). The 'necessity' of this fiction will be seen in the context of what is known as Deuteronomistic history. My argument will thus result in the question of whether it is legitimate to use laws (such as in Leviticus 18 and 20) regarding sexual conduct that were forged in a context of survival to determine normative principles for sexuality in our contemporary 21st-century context.

\section{QUEER THEORY}

To begin with, Teresa de Lauretis coined the term 'queer theory' in 1990 (Talburt \& Steinberg 2000:16). Etymologically, the word queer means across (Talburt \& Steinberg 2000:3). Queer theory (and by extension queer theology) engages in the 'crossing of borders' (Althaus-Reid 2003: 50). Queer theory challenges the very concept of 'normal' (Thiem 2007:469; Warner 1993:xxvi), and as such it questions the identity categories such as 'heterosexual' or 'homosexual', 'male' or 'female' (Pilcher \& Whelehan 2004:129; Tate 2007:293), as well as notions of what constitute legitimate ethnic boundaries (Stone 2001:22). ${ }^{1}$ Such questioning includes the very notion of essential sexual characteristics or 'essences' (Dreyer 2006:162) or ideas about 'gender cores' (Butler 2004:42; Talburt \& Steinberg 2000:21). Furthermore, queer theory focuses its efforts on the seemingly natural binary relationships (such as male and female) to explore the implicit or unspoken interdependencies that exist in such binary relationships (Stone 2001:26). In terms of sexuality, queer theory can be said in one instance to be leaning on Simone de Beauvoir's idea that 'one is not born a woman but becomes one' (Butler 2004:65). In other words, queer theory ${ }^{2}$ asserts that gender is not something that one is born with, but something that one grows into or is acculturated into. Queer theory challenges us in terms of how we come to understand ourselves as sexual individuals in relation to the greater community or culture in which we find ourselves situated (Stone 2001:22). In exploring the issue of homosexuality and the Bible, I shall be referring to two concepts that are elaborated on in the works of the prominent queer theorist Judith Butler (Stone 2001:25), namely performativity and interpellation.

1.The importance of queer theory's questioning of ethnic boundaries will become evident as we explore the role that the Bible plays in creating a Jewish national identity.

2.Queer theory differs from a 'gay hermeneutics of suspicion' (Althaus-Reid 2003:81) in that a gay hermeneutics of suspicion tends to look for heterosexual normativity (or heteronormativity) that is inherent in texts, whereas queer theory seeks to expose inconsistencies that are presented with regard to sexual binaries in texts (Stone 2001:29). 


\section{Performativity}

When it comes to the nature of sexuality or gender, Butler asserts that 'gender is a complexity whose totality is permanently deferred' (Butler 1990:16). One way to understand this statement is to assert that 'the body is not naturally "sexed"' (Spargo 1999:55). In other words, sex or gender is something that is said about the body, not something that comes out of or is intrinsic to the body. If this is the case, how then do we explain gender and sexuality? Firstly, one can say that 'gender ought not to be conceived as a noun or a substantial thing' (Butler 1990:112). Or to express it differently, gender can be linguistically understood or construed, not as a noun, but as a verb (Pilcher \& Whelehan 2004:59). In other words, gender, rather than being a 'naturally' occurring phenomenon (or object in the world), is a really fluid socially or culturally constructed reality. Following this line of reasoning, one can say that 'we do not behave in certain ways because $[\mathrm{SH}]$ of our gender identity' (Spargo 1999:56); rather, we have a certain gender identity because of the way we behave. Thus, for example, men are men because they behave in a 'manly' way; they do not behave in a manly way because they are firstly 'men' (or have a pre-existing inherent 'manly' essence).

In terms of Butler's theorising, the 'gendered subject' should be understood as the result of language, rather than the cause of language. To augment this idea, it can be asserted that identity categories 'are in fact the effects [SH] of institutions, practices, discourses with multiple and diffuse points of origin' (Butler 1990:74; Pilcher \& Whelehan 2004:58). Sexuality or gender can thus be described as an effect or outcome of language that is used (Butler 1993:187) in a particular culture or interpretive community (Plummer 1995:94). ${ }^{3}$

With regard to the idea that sexuality is an effect rather than a cause, Butler argues that crucial to and constitutive of sexual identity formation is the rehearsal of certain norms (Butler 1993:8), so that gender is a 'stylized repetition of acts' (Salih 2004:114). In describing gender in terms of 'performativity', or stylisation of acts, Butler is asserting that gender is something one does, and not something that one is. However, her concept of performativity is more complex than that, in that Butler is not reducing our sexuality to coital activity, or 'mere' role-playing, but rather that she is looking at the totality of how we express ourselves as individuals. So firstly, by describing gender in terms of performativity, Butler is not asserting that gender is something that is freely chosen, so that one can say, 'I choose to be gay', or 'I choose to be heterosexual'. Rather, gender is something that we are 'born' into, not in the sense that we are genetically predetermined as a particular gender, but in the sense that the culture that we are born into 'determines', through its own pre-existing systems of signification or language, the gender that we are (or 'have'). ${ }^{4}$ The significant crux of gender as performativity is that Butler is asserting that gender takes on its meaning in terms of language. Language not only determines the meaning of gender, but language itself is constitutive of gendered persons. Another way to put it is to say that, when we are born, the language of our natal community already exists, and thus certain notions or ideas of gender already pre-exist us, so that at birth we are simply placed in a 'position' within that system of linguistic signification, or verbal meaning, of language (Butler 2004:46). Our position or gender on the level of language alone then becomes determined by our linguistic situatedness (or genderedness) in relation to other words or

3. 'Interpretive communities' is a concept that Ken Plummer develops in his book Telling sexual stories. Power, change and social worlds (1995). Interpretive communities are communities that develop around people sharing the same experiences (political and sexual) with regard to identity issues. As a result, these communities develop common vocabularies with which to articulate and make sense of their experiences (Plummer 1995:94). In this way, interpretive communities provide individuals within those communities with a 'vocabulary of values' (Weeks 2000 :
vocabularies may include concepts like homosexual or heterosexual.

4.A typical example of such early gender enculturation in our Westernised society is the attitude or belief that baby boys should wear blue clothing, while baby girls should wear pink clothing, or that young boys should play with guns and toy truck, and young girls with dolls and tea sets. linguistic signifiers. Thus what we do, and the way we behave, are interpreted or understood by our pre-established position or positionality within language that we come to 'inherit' as a result of society associating certain body parts (or secondary sexual characteristics such as genitalia and body hair) with certain linguistic categories.

But with regard to this 'linguistification' of reality, a significant ramification is that language itself is not static, so that our positionality within the language structures that we find ourselves inhabiting is not indelible. In other words, the meaning of gender surrounding our bodies, which we have come to inherit, is not necessarily permanently tied to us throughout our lives. Not only is it possible for a $\operatorname{man}^{5}$ to come to have a different understanding of his genderedness or sexuality the older he becomes (as is the case with the 'coming out' experience of many gay men), but it is also possible that, on a cultural level, ideas concerning the expression of gender or sexuality can and do change. Thus, in terms of Butler's theory of performativity, gender is not seen as a biological absolute, but something that can be changed or expressed differently. To demonstrate that gender is not something that we are essentially born with, Butler is able to use the idea, or parody, of drag (Butler 2004:216), to assert that these 'positions' of gender within language can be challenged (Comstock \& Henking 1999:195). ${ }^{6}$ Thus men (in drag) wearing women's clothing is not only visually contentious, but challenges on a profound level our notions of maleness and femaleness. This is because these men in drag are not only wearing 'women's' clothes; they are also behaving differently from culturally assumed norms with regard to male or masculine conduct.

In the above line of reasoning, Butler uses Nietzsche's insight that 'there is no "being" behind doing, acting, becoming; the "doer" is merely a fiction imposed on the doing - the doing itself is everything' (Salih 2004:91); in other words, 'the psyche [or gender - $\mathrm{SH}$ ] is not in the body, but in the very signifying process $[\mathrm{SH}]$ through which that body comes to appear' (Salih 2004:134). Thus, to reiterate, there is no subject behind the doing, the doing itself constitutes the subject (Salih 2004:130), so that it can be said that gender, if subject to change, can be described as an open-ended process in that it has no fixed 'origin', nor has it any clear destiny (Salih 2004:90). This is because, 'sexuality always exceeds any given performance' (Salih 2004:131), due to the fact that no one person is ever the 'perfect' male or the 'perfect' female (Ruse 1988:9), so that 'the norm [of heterosexuality or even homosexuality - $\mathrm{SH}$ ] cannot be reduced to any of its instances ... neither can the norm be fully extricated from its instantiations' (Butler 2004:52). However what is it that constitutes the norm? If gender is 'just' a matter of performativity or linguistic positionality, why then does it seem like our genders or sexual orientation constitute so much of who and what we are (Comstock \& Henking 1999:196)? What can be said to be the web or matrix comprising the relationality in which gender as a term finds itself implicated or entwined? To answer this question we will look at Butler's development of the concept of interpellation, and the role that Deuteronomistic history plays in gender identification in terms of the Biblical narrative.

5.At this point I would like to make the reader aware that the discussion and use of Judith Butler's queer theory (in terms of performativity and interpellation) is androcentric, in that I apply her theory specifically to male homosexuality. There are at least two reasons for this. Firstly, the Old Testament texts that I refer to are themselves very androcentric, being created by an essentially patriarchal society of conservative male Jewish priests. Thus, when it comes to the issue of homogenital acts, the focus of the texts is on penetration or male sexual activity (Greenber 2004:85). Secondly, due to the focus being so much on male sexual activity, it can be argued that lesbianism is not something that the Old Testament or the Torah texts themselves address at all (Greenberg 2004:85-86).

6.It can be said that the process of performativity involves the aspect of reiteration or constant repetition. What is significant with regard to the reiterative aspect of or constant re that it whe performativity is that it become leading to instability (Burnus 2004:126). One possible reason for this is that, as with every with every iterative act comes slight difference. This introduction of difference is one way to understand how it is possible for Butler to argue that, intrinsic to the linguistic understanding of genderedness, is an inherent possibility for change. 


\section{Interpellation}

The role that language plays in gender formation and identity is demonstrated in the concept of interpellation. Originally formulated by Louis Althusser (Macey 2000:9), interpellation can be said to be the process through which an official brings a subject into 'being' by directly and verbally addressing them. For Butler, interpellation is an example of performative language, in that the naming act itself, or the verbal articulation that is directed at a subject, is the very vehicle that brings a subject into existence (Salih 2004:138). One consequence of this process of interpellation is that the culturally constructed language creates the illusion that its own created reality is the only reality that there is (Pilcher \& Whelehan 2004:76). ${ }^{7}$ And since 'all representations of reality are mediated through ideology [and thus language SH]' (Pilcher \& Whelehan 2004:76), there is no contestation on the part of those who find themselves (as homosexuals) interpellated in terms of the master ideology (heteronormativity). In one sense, the designation of homosexual is beyond the control of the person to whom it is directed. Being labelled as a homosexual is to be brought into 'existence' in terms of another person's understanding of reality (and 'sexual' reality in particular). However, this does not mean that there can be no resistance on the part of the ascribed or designated homosexual person, since ideology 'is also paradoxically and with promise, a resource, the means by which [one's - SH] transformation becomes possible' (Butler 1993:247). Thus, for example, the verbal abuse of 'fag!' or 'queer!' can be said to interpellate or bring into existence the queer subject. However, such abuse is subverted through reappropriation by the queer subject of the negatively intended term into something that the individual queer subject owns for themselves (Pilcher \& Whelehan 2004:129; Stone 2001:16; Weeks 2000:86). Such a phenomenon of re-appropriating pejorative labelling is aptly demonstrated in the history of Christianity, for the very word or term 'Christian' itself was intended to be a derogative term aimed at followers of Christ (Acts 11:26). However, the followers of Christ re-appropriated the term, and have subsequently worn it as a badge of honour and pride.

Thus it can be seen that, paradoxically, through the very medium of interpellation it is possible to 'constitute a truth of oneself through the act of verbalization itself' (Butler 2004:163). And so, in declaring oneself to be queer or gay, by coming out of the closet, one is, in the verbal declaration itself, reconstituting one's own existence, both publicly and in terms of self-ascribed linguistic signification. Problematic, however, is that the phrase 'I am gay' is both a performative act (Butler, in Morland \& Willox 2005:142), as well as a moment of yielding to interpellation, in that the above person is choosing a term that is already in common currency, and as such is a term that has been created by the 'other' (of culture and of language).

This problematic becomes evident in that, through the interpellative act, 'identity categories tend to [become - SH] instruments of regulatory regimes [SH]' (Salih 2004:121). What this means is that gender terms, such as 'gay' or 'heterosexual', are not simply neutral terms, but, intrinsic to them, have normative implications (Lance \& Tanesini, in Morland \& Willox 2005:171), as they form part of society's dominant discourse surrounding sexuality and sexual conduct. This normative implication can be understood by recalling how gender itself arises out of particular interpretive communities, as a story that unifies, or gives 'cosmic structure', to common shared experience. In other words, it is not possible 'just' to have sexual intercourse, since 'there is no sex that is not already gender' (Salih 2004:91), but every time that one has sexual intercourse one does or acts as or from a position of genderedness. Another way to understand this process is to say that a person conforms to a particular gender script (Lance \& Tanesini, in Morland \& Willox 2005:181). Thus, by being interpellated by another person or one's culture, as 'gay man' or 'heterosexual woman', this in turn creates certain

7.So, for example, heterosexuality is presented as the true reality of nature, while homosexuality is resented as a perversion or deviance from nature. social expectations of a person, certain behavioural scripts that come with being part of that category. An example of such a gender script is the instance in which homosexuals tend to be stereotyped as having 'feminine' behaviour, because that is the expected gender script associated with the term gay.

It is important to note once again that Butler does not deny the possibility that, in the construction of gender, there are possible 'extra-linguistic' factors that might contribute to one's sexuality (for example genetic factors).$^{8}$ Indeed, it can be said that, for Butler, 'language and materiality are not opposed, for language both is and refers to that which is material, [but - SH] what is material never fully escapes from the process by which it is signified' (Salih 2004:152). To put it another way, 'language and materiality are ... chiasmic in their interdependency' (Salih 2004:153). In other words, there is an area of overlap between linguistic discourse surrounding sexuality and the biological realities underlying sexual orientation.

The significance of the concepts of performativity and interpellation will become more evident as we consider the role of Deuteronomistic history in the development of negative attitudes towards homogenital acts, and subsequently towards homosexuality.

\section{DEUTERONOMISTIC HISTORY}

Biblical scholars studying the contents of the Old Testament Biblical text have for a long time noticed certain 'telling' clues in the text itself that give rise to the idea that the final form of the text that we have today was actually put together by redactors or editors at a later stage than the original composition of the individual fragmentary parts. And so we also have what can be identified as the 'Deuteronomistic history' of the biblical narrative, which includes the seven books of Deuteronomy, Joshua, Judges, I Samuel, II Samuel, I Kings and II Kings (Finkelstein \& Silberman 2001:13). The theory of Deuteronomistic history was developed by Martin Noth in 1943 (Person 2002:2), and is based on the idea that a guild of scribes belonging to the royal court of king Josiah (Person 2002:7) was instrumental in compiling the scriptures (particularly Genesis through to II Kings) in the format that we have them today. They are thought to have selectively compiled these scriptures, with emphasis on particular themes that suited their political and religious agenda. ${ }^{9}$ The development of Deuteronomistic history can be said to have taken place over the duration of two significant periods (Person 2002:83), the one being the reign of the king Josiah, and the other the post-exilic period, when the Jews returned from Babylonian captivity.

Josiah reigned as king of Judah between 640 and 609 BCE (Rogerson 1999:122), and was responsible for tremendous social and religious reforms in Judah (II Ki 23). Such reforms were enabled and heavily influenced by the defeat of the northern kingdom of Israel approximately a century or more before, as there was a resultant major immigration of people as refugees fled from the north and settled in and around Judah, and specifically in Jerusalem (Rogerson 1999:139, 147). This migration brought people with it who had skills and wealth that would enable a 'religious development and literary expression of national identity' (Finkelstein \& Silberman 2001:289). Previously, literary skills were not widespread, as writing tools and materials were very expensive and there simply was not enough manpower

8. Here I must admit that I am disappointed, in that so far in my readings of Butler I have not come across her addressing the issue of why some people are gay and others are not. In other words, while Butler does acknowledge that the link between 'gender identity and sexual orientation [is - SH] murky' (Butler 2004:79), she does not seem to directly address the issue of why the linguistic positionality of 'gay' more accurately expresses (or verbally describes) the reality or experiences of some men and not of others.

9. To quote Raymond Person, such themes included '1. The struggle against idolatry, 2 . The centralisation of the cult, 3 . Exodus, covenant and election, 4 . The monotheistic creed, 5 . Observance of the law and loyalty to the covenant, 6 . Inheritance of creed, 5. Observance of the law and loyalty to the covenant, 6. Inheritance of
the land, 7. Retribution and material motivation, 8. Fulfilment of prophecy, 9. The the land, 7. Retribution and material motivation,
election of the Davidic dynasty' (Person 2002:20). 
to sustain the demands of a large reading public. However, as noted, this poverty of literacy dissipated with the large southward migration of skilled and wealthy peoples.

And so, under contemporary prosperity and the reforms of Josiah, Jerusalem became the dominant centre of Jewish religion and politics (Finkelstein \& Silberman 2001:243; Person 2002:27; Theodore Mullen 1993:4). As a result of Josiah's reforms, the socalled 'Yahweh alone' cult (Finkelstein \& Silberman 2001:273) took centre stage in a Jewish notion of the divine (Finkelstein \& Silberman 2001:247), as priests began to consolidate a monotheistic understanding of Yahweh, and to consolidate the relevant religious texts that were to become authoritative in the worship of Yahweh. And because the destruction of the northern kingdom of Israel was still very fresh in the minds of these priests (in fact some of them probably found themselves living in Jerusalem because they themselves were refugees of those tragic events (Rogerson 1999:139, 147), there was intrinsic to the construction of the text the driving need to establish an identity for the purposes of survival. With such a need and the consolidation of a textual canon, the phenomenon of 'retrospective theology' (Finkelstein \& Silberman 2001:249) arose, in which already existing fragments of texts were fused together to form a continuous narrative, with contemporary concerns permeating the narrative structure and content of Biblical books. Such 'fusion' obviously involved a degree of selectivity in which some fragments were included in the Biblical narrative, and others were excluded (Theodore Mullen 1993:9). What guided this selectivity in turn were the contemporary seventh-century theological and political orientations of the priests or redactors who compiled or collated the Biblical text. Thus the compilation of the Biblical text involved the retelling of past events, in which those past events were framed in terms of the current ideological priorities. In other words, issues of the day were retrojected onto the past (Theodore Mullen 1993:14), in the sense that stories of the past as they are recounted in the Biblical narrative are infused with the priestly redactor's own seventh-century political and theological agenda. Of significance to this phenomenon of retrospective theology is that, at this time of the compilation of the Biblical narrative, a mysterious book was 'discovered' in the temple. Finkelstein and Silberman describe the significance of this discovery as follows:

That book, identified by most scholars as an original form of the book of Deuteronomy, sparked a revolution in ritual and a complete reformulation of Israelite identity [SH]. It contained the central feature of Biblical monotheism: the exclusive worship of one God in one place; centralized, national observance of the main festivals of the Jewish year (Passover, Tabernacles); and a range of legislation dealing with social welfare, justice, and personal morality.

(Finkelstein \& Silberman 2001:276)

And so we can see from this example of the book of Deuteronomy, the retrospective theology of the priestly redactors placed great emphasis in the collated texts on centrality of worship and the uniqueness of the Jewish identity as played out in the observance of special holy days, food laws and rules regarding social and personal conduct. Such rules invariably included issues of sexual conduct and the regulation of procreative activity.

As with the reforms of Josiah (Person 2002:27), another crucial period in the development of the format of the text as we have it today is the exile and post-exile period of Jewish history, which also overlaps with what is known as the 'second temple' Judaism (Rogerson 1999:157). It was the time when the southern kingdom of Judah was taken captive by the Babylonians, circa 586 BCE. Loss of land and living in a foreign country stimulated a focus on what it was to be a Jew. Sabbath observance, circumcision and dietary laws, as well as endogamous marriage laws and regulations around sexual conduct became means by which to define oneself as a Jew (Rogerson 1999:155). With the return of some of the Jews to Jerusalem, and under the influence and rulings of Ezra and Nehemiah, a Jewish identity was consolidated (Finkelstein \& Silberman 2001:361). And so 'a rewritten history of Israel was the best way for the exiles to reassert their identity' (Finkelstein \& Silberman 2001:303). With such a consolidation came a text that was to have a far reaching and profound influence on how later users of these texts, for example Christians, were to understand and formulate their own sense of identity (including sexual identity) in the world.

From the above discussion, what is significant about the form and content of the Biblical narrative that we have today is not so much the historical 'facts' that are recorded in its pages, but what we can learn about the interests and pressing concerns of the redactors who collated these Scriptures (Rogerson 1999:20). As noted, such interests reflect the concerns of the seventhcentury BCE 'Judahite' focus on the southern kingdom of Judah (Finkelstein \& Silberman 2001:45). Thus, for example, the redactors are at pains to emphasise the apparent righteousness of the southern kingdom of Judah, and the evil of the northern Kingdom of Israel (Finkelstein \& Silberman 2001:121). And so 'history' as recorded or collated by the Biblical redactors forms more of a foil for what is really the main concerns of the redactors, i.e. the presentation of theological and political ideals in an attempt to establish a 'defining and motivating text' that lies at the very heart of what it means to be a Jew in the world (Finkelstein \& Silberman 2001:229, 283; Rogerson 1999:149). Of significance is that such meaning of what it means to be a Jew influenced the presentation of ideals and meaning in the text as we have it today, whether theological or political (Rogerson 1999:75).

Deuteronomistic history is not only a narrative but can also be understood as a grand narrative, the 'grand narrative' of Scripture (Goheen 2008:475; House 2005:231; Larkin 2000:405). The term 'grand narrative' is a phrase used by Jean-François Lyotard (Hammer 1998:137) to describe the type 'of story that underlies, gives legitimacy, and explains the particular choices a culture prescribes as possible courses of action' (Taylor \& Winquist 2001:164). Deuteronomistic history presents us (on a narrative level) with a 'unique interpretation $[\mathrm{SH}]$ of universal history' (Goheen 2008:472). Thus Deuteronomistic history (Scripture) provided the Jew with an 'interpretive grid' (Weeks 2000:100) that enabled the Jew to have a firm and definite sense of self and nation amidst the chaos of Babylonian exile. Thus Deuteronomistic history is really a Jewish national grand narrative.

\section{POLITICS OF SURVIVAL}

It has been asserted that 'in times of social crisis, when national borders and identities are threatened, there is likely to be a concern with the maintenance of existing bodily boundaries [SH] and the purity of bodies' (Standing 2004:68; Stone 1996:13). This is clearly evident in the development of Deuteronomistic history, the development of a Jewish national grand narrative, the development of a particularly Jewish identity. In his book, Making sexual history (2000), Jeffrey Weeks asserts that 'identities have become narratives, built out of stories we tell each other in the various interpretive communities to which we belong' (Weeks 2000:64). The assertion that 'identity is shaped by narrative structures' (Schuegraf 2006:32) has particular significance for the issue of homosexuality and the Bible. Through the development of Deuteronomistic history, the Jews developed a narrative (Jewish national grand narrative) that enabled them to survive as a people in a time of severe crisis. Identities (including sexual) become 'necessary fictions' (Weeks 2000:84), in that we can see that this Biblical narrative was not merely a descriptive account of historical events, but was a story constructed with political ends in mind. Thus, as an attempt to establish meaning through narratively created identity structures, these narratives or stories invariably include in them socio-political ideals in one form or another, including ideals around social structures of sexual conduct (Rogerson 1999:22). This development of political ideals through the instrument of narrative structure took place against the background of what can be called a politics of survival. 
This is a term used by Frederic Homer in his commentary in Primo Levi and the politics of survival (Homer 2003:158). It is a term that I find particularly fitting to describe the context of the development of the Biblical grand narrative or Jewish national grand narrative. As evident in my above argument, I use the term 'politics of survival' to refer to this very process of a people using narratives to construct a strong sense of national identity, against a background in which such an identity is being threatened by extinction. The use of narrative in a politics of survival creates certain 'identity markers' (such as circumcision and Sabbath observance) that not only help to define what it is to be a Jew, but also what it is to behave like a Jew. Thus, the Jewish national grand narrative was created in a context of a politics of survival. This politics of survival, in turn, informed normative implications with regard to national behaviour, including sexual conduct.

\section{CONCLUSION}

Understanding the Biblical text as being a Jewish national grand narrative forged in the heat of a politics of survival helps us to realise that

although it is important to know that a particular act [homogenital - SH] is forbidden or permitted by the religious authorities of a culture, the meaning (sic) of sex cannot be reduced to the specific proscriptions and prescriptions [such as those in Leviticus 18 and $20-S H]$ which build up around it.

(Stone 1996:14)

Thus, what do Butler's insights mean in terms of a hermeneutics of sexual identity with regard to the issue of homosexuality and the Bible? We can come to understand using Butler's concept of performativity that 'gender', as construed in terms of the Biblical narrative, is not a biological given but a socially constructed reality. This social construction of gendered reality in terms of the Biblical narrative is the 'interpellative' process and result of the Jewish priestly redactors taking it upon themselves to define what constitutes the defining features of what it is to be a 'true' Jew.

However, when it comes to this interpellative definition of what it is to be Jewish, when we look at the New Testament, we can already see that at the very beginnings of Christianity, even though the Biblical narrative (or Jewish national grand narrative) was foundational to the Christian religion, Christians already had an ambivalent attitude towards it. Thus, a breakdown of the Jewish national grand narrative and its concomitant 'identity markers' can already be seen in the theology of Paul, so that it can be asserted that 'Paul no longer took the Torah at face value' (Germond \& De Gruchy 1997:192). Paul undermines (even negates) the identity markers of the Jewish national grand narrative in that, firstly, he relativises the Sinaitic covenant by implying that it is of lesser value than the covenant God made with Abraham (Gl 3:17). Secondly, he further implies that the observance of holy days is not necessary for salvation, and in fact might even be a definite hindrance to salvation (Gl 10). Thirdly, Paul insists that circumcision is no longer mandatory for salvation (Gl 5:1-6). And, finally, Paul goes on to imply that the Law, far from being a blessing, is really a curse (Gl 3:1-14), in fact the Law (though 'holy, just and good', Rm 7:12) is seen by Paul to be our enemy (Eph 2:14). Most powerfully of all, Paul seems to announce (perhaps without realising the full consequences and implications of such an announcement) the dissolution and breakdown of the Jewish national grand narrative by declaring that the middle wall of division (Jewish nationalism?) has been abolished by the work of Jesus (Eph 2:14). Having said this, however, it can be added that it is strange that Paul still seems to hold on to this national grand narrative in his condemnation of homogenital acts (Rm 1:26-27). I would hypothesise that this is probably because Paul is still trying to hang onto the Jewish sense of 'cosmic order' that is presented in the creation myth of Genesis chapters one and two, in which there are 'natural' (Rm $1: 27)$ categories, categories which, if transgressed, would lead to confusion and ultimately to idolatry ( $\mathrm{Rm} 1: 23)$. However, very tellingly, already in Galatians 3:29 Paul is beginning to let go of the creation 'categories' of male and female when he writes (The Amplified Bible - emphasis added): 'There is neither Jew nor Greek, there is neither slave nor free, there is not male or female: for you are all one in Christ Jesus!'

Thus, while there is a negative stance in Paul towards homogenital activity, there is also ambivalence in Paul towards the very texts (Pentateuch and Deuteronomistic history) that would support such a negative stance. And so Paul's ambivalent stance toward the scriptures can become a means by which it can be asserted that 'we [need - SH] not be the prisoners of a textual past' (Pinnock 2000:72). There is scope for us to go beyond a superficial reading of the Biblical narrative to a deeper understanding of the political currents that were instrumental in its composition. We would then see that the Biblical text is historically situated, addressing the specific needs and questions of a particular people at a particular time in their history, when a hostile political environment threatened their survival as a people. Acknowledging the historical situatedness of the Biblical text would then help us to have a more balanced and fair approach towards minorities within the church who are persecuted and marginalised because of their sexual orientation.

\section{REFERENCES}

Althaus-Reid, M., 2003, The queer God, Routledge, New York.

Bradshaw, T. (ed.), 2003, The way forward? Christian voices on homosexuality and the Church, William B. Eerdmans, Cambridge.

Burrus, V., 2004, The sex lives of the saints. An erotics of ancient hagiography, University of Pennsylvania Press, Pennsylvania.

Butler, J., 1990, Gender trouble, Routledge, New York.

Butler, J., 1993, Bodies that matter. On the discursive limits of 'sex', Routledge, New York.

Butler, J., 2004, Undoing gender ${ }_{L}$ Routledge, New York.

Comstock, G.D. \& Henking, S.E. (eds.), 1999, Que(e)ring religion. A critical anthology, Continuum, New York.

Dreyer, Y., 2006, 'Prejudice, homophobia and the Christian faith community', Verbum et Ecclesia 27(1), 155-173.

Finkelstein, I. \& Silberman, N., 2001, The Bible unearthed. Archeology's new vision of ancient Israel and the origin of its sacred texts, Touchstone, New York.

Germond, P. \& De Gruchy, S., 1997, Aliens in the household of God. Homosexuality and Christian faith in South Africa, David Philip, Cape Town.

Goheen, M., 2008, 'The urgency of reading the Bible as one story', Theology Today 64, 469-483.

Greenberg, S., 2004, Wrestling with God and men. Homosexuality in the Jewish tradition, The University of Wisconsin Press, Wisconsin

Hammer, D., 1998, 'What the Iliad knows: Why Lyotard is wrong about grand narratives', Soundings 81(1-2), 137-156.

Homer, F.D., 2003, 'Primo Levi and the politics of survival', Shofar 21(2), 158-160.

House, P.R., 2005, 'Examining the narratives of Old Testament narrative: an exploration in Biblical theology', Westminster Theological Journal, 67, 229-245.

Jung, P.B. \& Coray, J.A., 2001, Sexual diversity and Catholicism. Toward the development of moral theology, The Order of St. Benedict, Minnesota.

Larkin, W.J., 2000, 'The recovery of Luke-Acts as 'grand narrative' for the church's evangelistic and edification tasks in a postmodern age', Journal of the Evangelical Theological Society 43(3), 405-415.

Macey, D., 2000, Dictionary of critical theory, Penguin, New York.

Morland, I. \& Willox, A. (eds.), 2005, Queer theory, Palgrave Macmillan, New York.

Person, R.F., 2002, The Deuteronomistic School. History, social setting and literature, Society of Biblical Literature, Atlanta. 
Pilcher, J. \& Whelehan, I., 2004, 50 key concepts in gender studies, Sage, London.

Pinnock, C.H., 2000, 'Biblical texts - past and future meanings', Journal of the Evangelical Theological Society 43(1), 71-81.

Plummer, K., 1995, Telling sexual stories: Power, change, and social worlds, Routledge, New York.

Punt, J., 2007, 'Romans 1:18-32 amidst the gay-debate: Interpretive options', HTS Teologiese Studies/Theological Studies, 63(3), 965-982.

Rogerson, J., 1999, Chronicle of the Old Testament kings. The reignby-reign record of the rulers of ancient Israel, Thames and Hudson, London.

Ruse, M., 1988, Homosexuality. A philosophical inquiry, Blackwell, Oxford.

Salih, S. (ed.), 2004, The Judith Butler reader, Blackwell, Oxford.

Schuegraf, O., 2006, 'Telling God's stories again and again reflection on remembrance and reconciliation', Modern Believing 47(3), 31-42.

Spargo, T., 1999, Foucault and queer theory. Postmodern encounters, Icon Books, London.
Standing, E., 2004, 'Homophobia and the postmodern condition', Theology \& Sexuality 10(2), 65-72.

Stone, K., 1996, Sex, honour and power in the Deuteronomistic history, Sheffield Academic Press, Sheffield.

Stone, K., 2001, Queer commentary and the Hebrew Bible, The Pilgrim Press, Cleveland.

Talburt, S. \& Steinberg, S.R. (eds.), 2000, Thinking queer: Sexuality, culture and education, Peter Lang, New York.

Tate, W.R., 2007, Interpreting the Bible. A handbook of terms and methods, Hendrickson Publishers, Massachusetts.

Taylor, V.E. \& Winquist, C.E. (eds.), 2001, Encyclopedia of postmodernism, Routledge, London.

Theodore Mullen, E., 1993, Narrative history and ethnic boundaries, Scholars Press, Atlanta.

Thiem, A., 2007, No gendered bodies without queer desires: Judith Butler and Biblical gender trouble, Old Testament Essays 20(2), 456-470.

Warner, M. (ed.), 1993, Fear of a queer planet. Queer politics and social theory, University of Minnesota Press, Minneapolis.

Weeks, J., 2000, Making sexual history, Blackwell, Oxford. 